\title{
Letter to the Editor: No immunophenotyping in peripheral blood of prostate cancer patients treated with neoadjuvant Rituximab?
}

\author{
Paulius Bosas ${ }^{1}$, Gintaras Zaleskis ${ }^{2^{*}} \mathbb{D}$, Vita Pasukoniene ${ }^{2,3}$ and Feliksas Jankevicius ${ }^{1}$
}

\section{Dear Editor,}

The paper by Ryan et al. [1] in your recent issue addresses intriguing data on Rituximab ( $\mathrm{Rx}$ ) immunomodulation in prostate cancer ( $\mathrm{PCa})$ neoadjuvant setting. The report on the first 8 participants from author's trial (NCT01804712) is appreciated since the complexity of similar studies quite often results in a termination or withdrawal. However, we would like to point out some downsides in the above-mentioned publication. The cornerstone statement that "...high B cell density is associated with biochemical failure" refers to the author's own previous publication [2]. However, this reference has nothing to do with biochemical failure. Even the higher density of B cells in recurrent tumors cannot be considered a surrogate parameter of biochemical failure. Growing tumors can passively induce recruitment of immune cells into the prostate microenvironment as a result of concomitant inflammation [3]. The relationship between tumor infiltrating cells and clinical outcomes for $\mathrm{PCa}$ is still debatable. The authors concluded that Rx treatment applied prior to prostatectomy reduced tumor infiltration density of B and T-cells. However, Rx is well known to specifically deplete a $\mathrm{T}$ cell subset which also co-express $\mathrm{CD} 20+[4,5]$. As a matter of fact, the double positive $\mathrm{CD} 20+\mathrm{CD} 3+$ lymphocyte was demonstrated

This comment refers to the article available at https://doi.org/10.1186/s1296 7-020-02370-4.

*Correspondence: gintaras.zaleskis@nvi.lt

${ }^{2}$ Laboratory of Immunology, National Cancer Institute, P. Baublio 3b, Vilnius, Lithuania

Full list of author information is available at the end of the article to be a specific marker of therapeutic response in rheumatoid arthritis patients receiving Rx [5]. Isn't it possible that similar mechanisms were involved in $\mathrm{PCa}$ patients treated with $\mathrm{Rx}$ ? The statement that there was a demonstration of "the inter-dependence between B and T-cells in prostate cancer..." is also questionable since the authors do not provide any evidence of double positive CD20+CD3+lymphocyte absence in tumorous tissue. One can notice that CD20+ B cell and CD 3+T cell infiltration scores in tumor tissue provided in Tables 2 and 3 of the paper are almost identical. This raises the question if an alternative explanation of the phenomenon might also be valid. Could it be that some specific B cell phenotype conversions or infiltration patterns were induced by $\mathrm{Rx}$ treatment? Unexpectedly, the peripheral blood $\mathrm{T}$ and $\mathrm{B}$ subset monitoring were not reported in this paper, although the peripheral blood B cell enumeration was originally planned as a secondary outcome measure (NCT01804712). Four out of 8 patients (Fig. 3) exhibited PSA rise while being on $\mathrm{Rx}$ treatment for only 29 days (one patient displayed a steep $40 \%$ PSA increase). We would suggest adhering to weekly PSA monitoring in the future if this study will continue. Rx was shown to induce paradoxical IgM and serum viscosity increase in some hematological malignancies [6], leading to increased morbidity. Therefore, it might be premature to rule out the fact that $\mathrm{Rx}$ treatment could occasionally provoke PCa progression. Unfortunately, the PSA data on day 29 of the control group participants was not provided. This would have been helpful to understand if some PSA flares in the interventional group were merely accidental (laboratory error?).

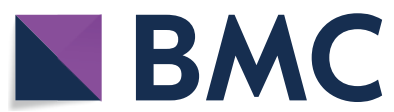

c) The Author(s) 2020. This article is licensed under a Creative Commons Attribution 4.0 International License, which permits use, sharing, adaptation, distribution and reproduction in any medium or format, as long as you give appropriate credit to the original author(s) and the source, provide a link to the Creative Commons licence, and indicate if changes were made. The images or other third party material in this article are included in the article's Creative Commons licence, unless indicated otherwise in a credit line to the material. If material is not included in the article's Creative Commons licence and your intended use is not permitted by statutory regulation or exceeds the permitted use, you will need to obtain permission directly from the copyright holder. To view a copy of this licence, visit http://creativeco mmons.org/licenses/by/4.0/. The Creative Commons Public Domain Dedication waiver (http://creativecommons.org/publicdomain/ zero/1.0/) applies to the data made available in this article, unless otherwise stated in a credit line to the data. 
This letter is not intended to provide a critique of an interesting study. We only want to draw attention to the complexity of Rx effects on therapeutic B cell modulation. Also, we would like to point out the necessity to explore extensive lymphocyte phenotyping in blood once patients are treated with B lymphocyte depleting drug.

\section{Acknowledgements}

Not applicable.

\section{Authors' contributions}

All authors contributed equally. All authors read and approved the final manuscript.

\section{Funding}

Not applicable.

\section{Availability of data and materials}

Not applicable.

Ethics approval and consent to participate

Not applicable.

\section{Consent for publication}

Not applicable.

\section{Competing interests}

The authors declare that they have no competing interests.

\section{Author details}

${ }^{1}$ Medical Faculty, Vilnius University, Vilnius, Lithuania. ${ }^{2}$ Laboratory of Immunology, National Cancer Institute, P. Baublio 3b, Vilnius, Lithuania. ${ }^{3}$ Vilnius Gediminas Technical University, Vilnius, Lithuania.

Received: 22 July 2020 Accepted: 21 August 2020

Published online: 01 September 2020

\section{References}

1. Ryan ST, Zhang J, Burner DN, et al. Neoadjuvant rituximab modulates the tumor immune environment in patients with high risk prostate cancer. J Transl Med. 2020;18:214.

2. Woo JR, Liss MA, Muldong MT, et al. Tumor infiltrating B-cells are increased in prostate cancer tissue. J Transl Med. 2014;12(1):30.

3. Strasner A, Karin M. Immune infiltration and prostate cancer. Front Oncol. 2015;5:128.

4. Schuh E, Berer K, Mulazzani M, et al. Features of Human CD3+CD20+T Cells. J Immunol. 2016;197(4):111.

5. Wilk E, Witte T, Marquardt N, et al. Depletion of functionally active CD20+T Cells by rituximab treatment. Arth Rheum. 2009;60:3563.

6. Treon SP, Branagan AR, Hunter Z, et al. Paradoxical increases in serum IgM and viscosity levels following rituximab in Waldenstrom's macroglobulinemia. Ann Oncol. 2004;15(10):1481.

\section{Publisher's Note}

Springer Nature remains neutral with regard to jurisdictional claims in published maps and institutional affiliations.
Ready to submit your research? Choose BMC and benefit from:

- fast, convenient online submission

- thorough peer review by experienced researchers in your field

- rapid publication on acceptance

- support for research data, including large and complex data types

- gold Open Access which fosters wider collaboration and increased citations

- maximum visibility for your research: over $100 \mathrm{M}$ website views per year

At BMC, research is always in progress.

Learn more biomedcentral.com/submissions 